\title{
P02.165. A comparative effectiveness trial of high-quality vitamin D3 nutritional supplements to replete serum vitamin D
}

\author{
M Traub $^{1 *}$, R Bradley ${ }^{2}$, J Finnell ${ }^{2}$ \\ From International Research Congress on Integrative Medicine and Health 2012 \\ Portland, Oregon, USA. 15-18 May 2012
}

\section{Purpose}

The primary aim is to compare the change in serum 25OHD concentration between three forms of supplemental vitamin D3: a lipid-emulsified form administered in a sesame oil base, a non-emulsified chewable tablet, and a non-emulsified form administered to 25-hydroxycholecalciferol (25-OHD) insufficient $<33 \mathrm{ng} / \mathrm{ml}(75 \mathrm{nmol} / \mathrm{ml})$ patients. The secondary aim is to compare the proportion of participants reaching an "optimal" 25-OHD concentration $\geq 33 \mathrm{ng} / \mathrm{ml}(75 \mathrm{nmol} / \mathrm{ml})$ between Vitamin D supplement groups following supplementation.

\section{Methods}

This three-arm, randomized clinical trial compared the difference in serum 25-OHD concentration between the three arms at baseline and after random administration of one of the three vitamin $\mathrm{D}$ preparations for 12-weeks at a dosage of 10,000 IU Vitamin D per day ( $\mathrm{N}=60$ vitamin $\mathrm{D}$ insufficient subjects and $\mathrm{N}=30$ sufficient controls).

\section{Results}

Enrollment occurred from August 2010 to August 2011. Vitamin D insufficient, age-eligible participants were enrolled in the study ( $\mathrm{N}=66$ ), with the addition of sufficient controls $(n=37)$. Overall loss to follow up was $n=11$ (16.7\%). Between group differences were not significant for age, gender, height, weight or baseline Vitamin D 25 status. One-way analysis of variance (ANOVA) was used to estimate the difference in between group means. The mean unadjusted intra-group increase in serum 25-OHD were: Group A, 33.3 ng/mL (95\%CI 24.1 - 42.4); Group B, $33.5 \mathrm{ng} / \mathrm{mL}$ (95\%CI $19.6-47.4 \mathrm{ng} / \mathrm{mL})$; Group C, 53.6
(95\%CI 40.7 - 66.4). The serum levels of 25OHD were significantly different between groups $(\mathrm{p}=0.0215)$, while the serum levels of $1,25-\mathrm{OH} 2 \mathrm{D}$ did not reach between group significance $(\mathrm{p}=0.4850)$. The proportion of participants reaching $25-\mathrm{OHD} \geq 33 \mathrm{ng} / \mathrm{ml}$ were: Group A 100\%; Group B 82\%; and Group C 100\%.

\section{Conclusion}

Between group differences reached significance for mean change in 25-OHD status. Final analysis of results will adjust for confounding, after which the treatment arm assignments will be un-blinded. Analysis of cardio-metabolic data, Klotho protein expression and TLR-4 expression are in process.

\section{Author details}

${ }^{1}$ Lokahi Health Center, Kailua Kona, USA. ${ }^{2}$ Bastyr University, Kenmore, USA.

Published: 12 June 2012 